\title{
O CAPITAL IMOBILIÁRIO E O SEU PAPEL NO PROCESSO DE FORMAÇÃO DE NOVAS CENTRALIDADES E DE VERTICALIZAÇÃO NA REGIÃO METROPOLITANA DE FLORIANÓPOLISISC
}

\author{
Margaux Hildebrandt Vera; Márcio Rogério Silveira
}

Universidade Federal de Santa Catarina (UFSC)

\section{Resumo}

O processo de verticalização está vinculado ao desenvolvimento capitalista do setor financeiro-imobiliário, no qual agem as forças de reprodução do capital por meio da construção civil. Diante disso, o objetivo deste artigo é demonstrar que os setores com processos de verticalização na área conurbada da Região Metropolitana de Florianópolis (RMF) foram impulsionados pelos poderes públicos municipais para o benefício de determinados grupos econômicos e retratar o desenvolvimento da cidade. Tais setores consolidaram as centralidades e contribuem para o adensamento dos fluxos de circulação, sem prever as repercussões que causariam para o espaço. Nessa perspectiva, analisaremos as novas áreas com processos de verticalização, a fim de desvendar as atuais dinâmicas da indústria da construção civil sobre o espaço urbano.

Palavras-chave: Verticalização, Indústria da construção civil, Espaço urbano, Centralidades urbanas, Área conurbada da Região Metropolitana de Florianópolis.
Abstract

The verticalization process is linked to the capitalist development of the financial-real estate sector, in which the forces of reproduction of capital act through civil construction. The objective of this article is demonstrate that the sectors with processes of verticalization in the conurbation area of Florianópolis, were pushed by the municipal authorities to benefit the economic monopolies, as well as to portray the city development. As well, the verticalization consolidate the urban centralities and contributed to increase circulation flows without foreseeing the repercussions that would cause to the urban space. In this perpective, we will analyze the new sectors with processes of verticalization to unveil the current dynamics of the construction industry over urban space.

Key words: Verticalization, Construction industry, Urban space, Urban centralities, Conurbation area of Florianópolis.

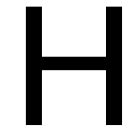

istoricamente, o processo de verticalização esteve ligado às condições particulares da formação das cidades norte-americanas e do próprio estágio de desenvolvimento capitalista, cujos fatores decorrem da grande concentração urbana, do incremento da divisão do trabalho, do preço da terra elevado, das áreas funcionalmente especializadas e do liberalismo da legislação (SOMEKH, 1987). Souza (1994, p.135) salienta que se pode definir a verticalização como "[...] a resultante, no espaço produzido, de uma estratégia entre múltiplas formas do capital - fundiário, produtivo, imobiliário e financeiro, que cria o espaço urbano". Tal fato é definido pelos 
diferentes agentes sociais e interesses econômicos que envolvem, produzem e organizam o espaço urbano. Por sua vez, a verticalização é responsável pelo incremento na construção material das cidades, com drásticas transformações na paisagem, além de reforçar os processos de metropolização.

Consequentemente, a verticalização é o processo que consolida as centralidades urbanas, pois nelas se produzem concentrações de atividades e surgem novas áreas de acumulação para oferecer mais impulso às relações capitalistas. Para Lojkine (1997), nessas centralidades agem com força as economias de aglomeração, nascidas da justaposição espacial das diferentes funções do capital e do conjunto das condições gerais da produção, em que a socialização da cooperação territorial atinge as novas formas de urbanização monopolista, dentre elas, a verticalização.

Dessa forma, a centralidade deve ser pensada no plano da dialética, na medida em que emerge como movimento de construção, destruição e reconstrução da cidade (LEFEBVRE, 2008 [1970]). A verticalização causa uma ruptura na lógica de crescimento tradicional da malha urbana (centro-periferia), a setorizando e concentrando. Esse processo influencia diretamente o movimento de reprodução do capital, fazendo eclodir espaços de consumo, reestruturando a forma urbana regional, já que adensa contundentemente a área que ocupa.

A área conurbada da Região Metropolitana de Florianópolis (RMF), objeto deste estudo, está conformada pelos municípios de: Florianópolis (485.838 hab.), São José (239.718 hab.), PaIhoça (164.926 hab.), Biguaçu (66.558 hab.) e Santo Amaro da Imperatriz (22.609 hab.). Em alguns setores desses municípios estão concentradas dinâmicas de verticalização intensa, como, por exemplo, no bairro Centro e o setor da Beira Mar Norte, no município de Florianópolis, em ambas localidades a densidade pode chegar até 26.557 hab. $/ \mathrm{km}^{2}$ (IBGE 2010), predominando os edifícios de doze a dezoito andares. Essas áreas possuem fortes dinâmicas urbanas e condicionantes que estão sujeitos à hierarquia que Florianópolis exerce como capital do estado de Santa Catarina. O centro de Florianópolis é o polarizador dos locais de empregos, residências, comércio e serviços, sendo que todos os outros bairros, e até os outros municípios, guardam estreita relação de deslocamentos pendulares com ele. O segundo centro concentrador de atividades urbanas é o setor de Kobrasol e Campinas, em São José, onde a densidade chega a 31.838 hab. $/ \mathrm{km}^{2}$ e com viabilidade para edifícios de até 21 andares.

No contexto das transformações ocorridas, nas primeiras décadas do presente milênio, novas centralidades com processos de verticalização vêm sendo impulsionadas na região, produto da expansão urbana e das atividades imobiliárias. Elas estão localizadas no município de Palhoça, no setor de Pagani e Pedra Branca, e foram ambas originadas por grandes empresas incorporadoras, criadoras dos loteamentos que levam os mesmos nomes. Ambas as centralidades se caracterizam pela construção de prédios verticais de alto padrão com usos mistos. A aparição desses subcentros urbanos ainda não atinge grande influência na rede urbana local, já que essa se encontra em processo de produção e ocupação.

Com tudo isso, a alta densidade populacional na Região Metropolitana de Florianópolis ocupa somente $7 \%$ do seu território, sendo o restante conformado por áreas residenciais que possuem densidades baixas (35\%) ou muito baixas (52\%). Isso implica também a periferia que possui um alto poder de expansão, via transformação do espaço rural em urbano. Vejamos o seguinte mapa de densidade demográfica por setores: 


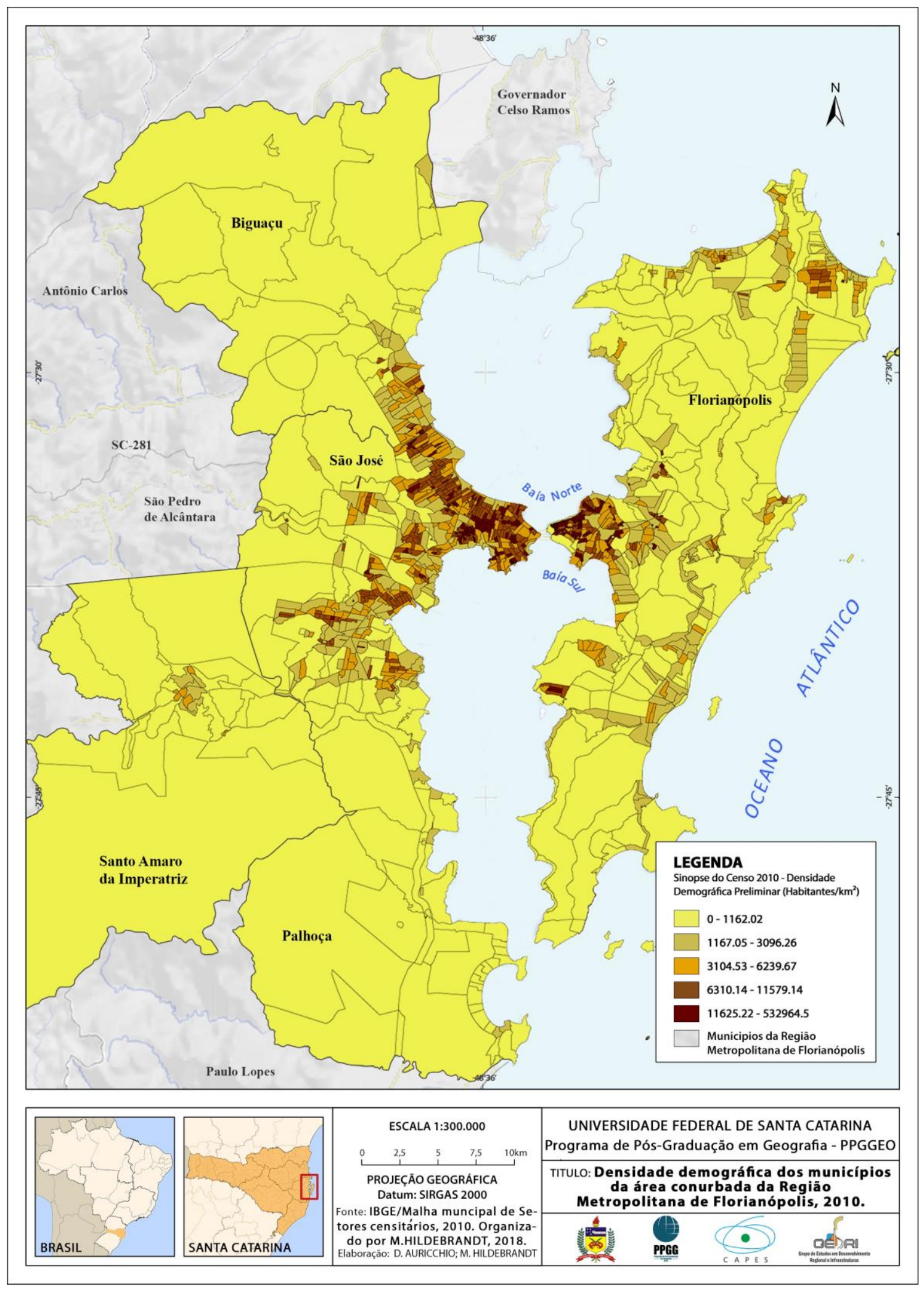

Mapa 01. Densidade demográfica dos munícipios da Área Conurbada da Região Metropolitana de Florianópolis - 2010. Fonte: IBGE - Malha Municipal de Setores Censitários, 2010. Organizado por M. Hildebrandt (2018). 
Segundo o mapa apresentado, existem diversas densidades demográficas na área de estudo, predominando as densidades muito baixas (de 0 a $1.162,02$ hab. $/ \mathrm{km}^{2}$ ). Por exemplo, 73\% dos setores urbanizáveis do município de Palhoça, possuem densidades muito baixas localizadas nas áreas periurbanas. Por sua vez, Palhoça tem alguns pequenos setores dentro dos bairros mais antigos como Ponte do Imaruim e Passa Vinte, com uma densidade que pode chegar a ser de $10.464 \mathrm{hab} . / \mathrm{km}^{2}$ (IBGE, 2010), onde predominam casas terras e sobrados.

Em Biguaçu os setores mais adensados conformam só o 1\% do total do território e se localizam próximos a São José e no centro histórico, nesses setores a densidade pode chegar até $12.791 \mathrm{hab} . / \mathrm{km}^{2}$. A área urbanizável do município possui uma densidade predominantemente baixa que corresponde 99\% do seu território (IBGE, 2010). Por sua vez, Santo Amaro da Imperatriz tem a densidade habitacional mais baixa de todos os municípios que conformam nossa área de estudo, isto se deve a que nas zonas urbanizáveis não há ocupação, há presença de glebas de terra de grande porte, misturando os usos residenciais com áreas de produção agrária e turística, só na sua parte central a densidade pode chegar até 3.400 hab./km² (IBGE, 2010).

Os distintos valores de densidades habitacionais podem ser corroborados no espaço em diversas tipologias de assentamento populacional (mais densas e menos densas), isso dá como resultado uma malha urbana nada homogênea (mas articulada, por mais que a mobilidade e acessibilidade sejam consideradas precárias), onde alguns setores se destacam pelo processo de verticalização intenso, e outros, por terem muitos vazios urbanos que correspondem a áreas subutilizadas.

Vejamos o seguinte gráfico sobre a comparação das densidades habitacionais. 


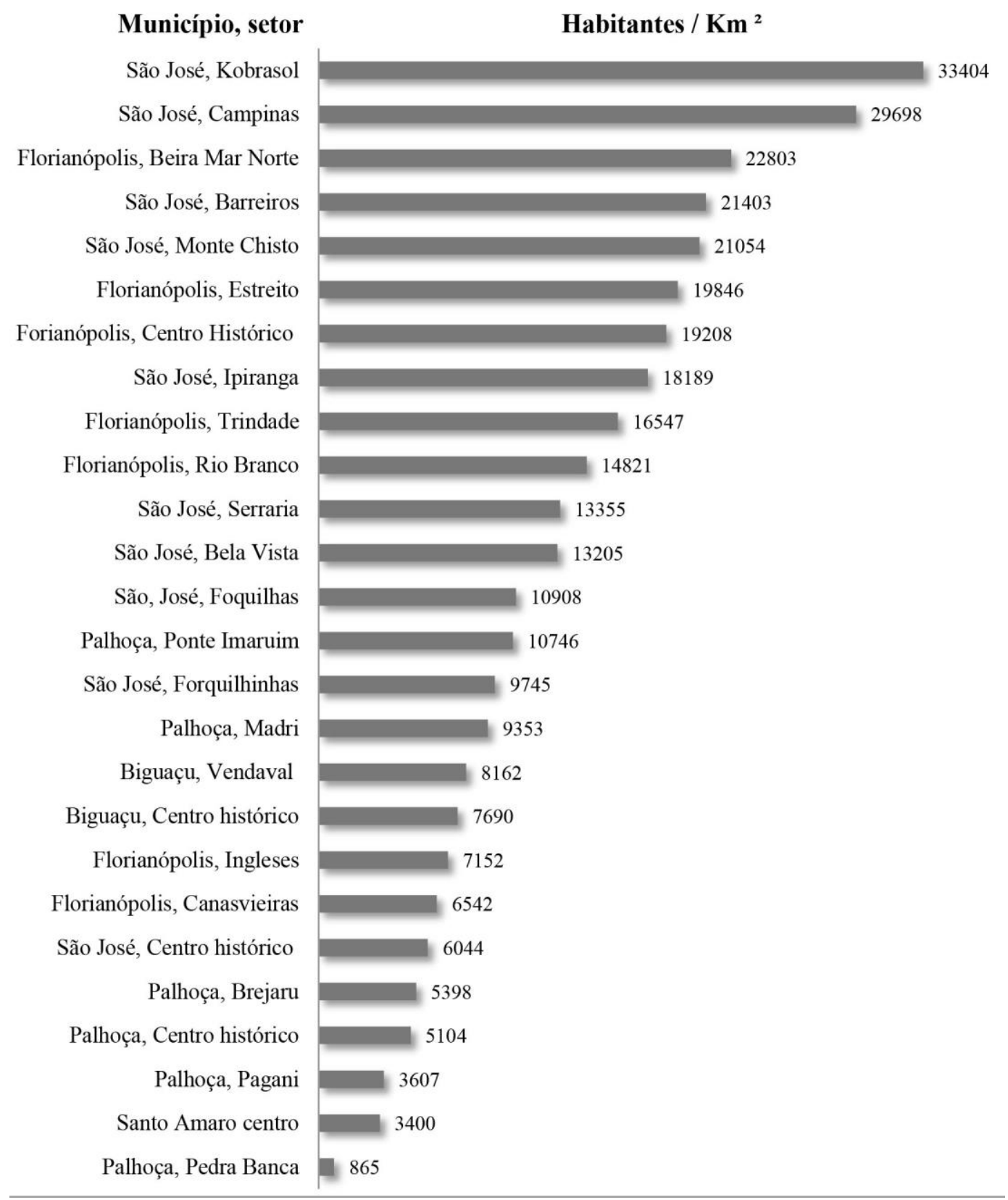

Gráfico 1. Comparação de densidades habitacionais, segundo a sinopse por setores do IBGE, censo 2010, na área conurbada da RMF. Fonte: IBGE - Malha municipal de setores censitários 2010. Organização: M. Hildebrandt, março 2018.

A comparação das densidades demográficas confirma que Campinas e Kobrasol são os setores de maior densidade habitacional da área conurbada, seguido pelo setor da Beira Mar Norte, em Florianópolis. Conforme mostra o gráfico, diferente de outras cidades, os centros históricos da área de estudo não coincidem em nenhum caso com as maiores densidades demográficas. Isso aconteceu devido ao surgimento de novas centralidades nos finais do século XX, derivadas da viabilidade municipal para o aumento de pavimentos na construção de novos prédios, uma 
lógica que é concomitante aos interesses do mercado imobiliário, mas que elimina as atividades pré-capitalistas, especialmente as de base rural.

A análise das densidades demográficas dos setores do IBGE também demonstra que dentro de um mesmo bairro podemos achar distintos tipos de densidade demográfica, pois a configuração da nossa área de estudo é muito variada, conforme assinalamos anteriormente. A verticalização de uma área da cidade, seja por meio de prédios de moradia, edifícios de comércio, ou de escritórios particulares, impulsiona o adensamento populacional das parcelas de solo, criando maiores fluxos, maiores relações com o espaço e maior necessidade de meios de consumo coletivos, como a mobilidade e o transporte. Uma cidade que funciona majoritariamente com o automóvel privado, com centralidades especializadas e fechadas, como centros administrativos e de negócios, áreas turístico-culturais exclusivas, shoppings centers de alto padrão, edifícios símbolo de grandes empresas etc., não facilita o progresso da cidadania e acentua as tendências de segmentação, individualismo e exclusão (BORJA \& MUXí, 2000, tradução nossa).

É por esse motivo que o ideal seria possuir densidades habitacionais médias, com variadas atividades urbanas, numa trama compacta e homogênea, que favoreçam o maior aproveitamento das infraestruturas instaladas e o uso do espaço público. Mas na Região Metropolitana de Florianópolis, além das barreiras institucionais, existem limitantes naturais que impedem que a malha urbana seja regular, tais como: seu relevo geográfico é variado e é possuidora de Unidades de Conservação Natural, áreas afetadas por inclinações protegidas e as áreas afetadas pela rede hídrica e proteção de recursos aquáticos , onde não é possível o assentamento humano, nem a exploração de nenhum tipo (FLORIANÓPOLIS, 2015).

Por outro lado, há uma pressão muito grande que age sobre o uso do solo, que é seu valor de troca. Por esse fator, o setor financeiro-imobiliário atua por meio da indústria da construção civil para direcionar a localização dos seus produtos conforme seus interesses. A seguir veremos qual é o papel dos oligopólios dessa indústria no início do processo de verticalização nas centralidades na área de estudo.

\section{O importante papel dos monopólios da construção civil no processo de verticaliza- ção}

A partir da década de 1960, na área de estudo, inicia-se um ciclo de expansão urbana gerenciada pelos agentes produtores do espaço, baseados numa realidade onde a cidade surgiu como um produto ou mercadoria. A complexidade das ações destes agentes incluem práticas que levaram a um constante processo de reorganização espacial além de arranjos empresariais e institucionais que eles produziam a partir de suas demandas e conflitos. Verificamos que na área de estudo os agentes produtores do espaço estão setorizados, formando monopólios e parcerias, e por outro lado, essas mesmas empresas excluem espaços, atividades, ou até mesmo outras empresas que não rendem lucros ou que ameaçam seus ganhos.

A indústria da construção civil intensificou sua atuação, edificando prédios que se destinavam basicamente à instalação de instituições públicas, hotéis, bancos, escritórios ou lojas, também chamados de edifícios comerciais, como descreve Mamigonian (1987). Temos, por exemplo, 
que as primeiras grandes construtoras do período de 1950 a 1960 foram a Ceisa, A. Gonzaga e a Emedaux, todas com origem em Florianópolis, construíram edifícios comerciais no centro do município com até doze pavimentos, chegando a atingir, em 1975, uma média de doze obras ao mesmo tempo (CAMPOS, 2010, p.142).

Por outro lado, temos a construção de edifícios residenciais na Avenida Rubens de Arruda Ramos, hoje conhecida por Beira Mar Norte, a qual iniciou seu adensamento nos anos 1960, foi destinada à construção de prédios de oito andares. As protagonistas das obras foram as construtoras Planel, Daros, Espaço Aberto e Engecal. Essas empresas mudaram radicalmente o perfil urbano da área, que anteriormente era composto por chácaras e sobrados, por edifícios verticais de alto padrão para a classe média-alta. Por muito tempo, o planejamento urbano foi embasado num modelo relativamente arcaico, com base na tradição portuguesa, a ocupação ocorria ao longo de avenidas e ruas estreitas, meândricas, de topografias variadas e com infraestruturas precárias (saneamento, águas pluviais e fluviais e calçamento). Fato que leva a estruturas do passado, as quais permanecem como rugosidades, presentes até hoje no tipo de ocupação do solo, isto é, na organização do espaço urbano da RMF e especificamente na capital do estado.

Por sua vez, na década de 1970, a verticalização e os grandes investimentos viários estiveram incentivados pelas propostas de planos urbanos, como o "Plano de Desenvolvimento Integrado da área Metropolitana de Florianópolis" (SUGAI, 2015). Nesse Plano, o modelo de desenvolvimento esteve baseado em propostas viárias, tinha como princípio a implementação de edifícios de alta densidade, comunicados por grandes vias expressas como artérias, e o automóvel formava parte integral e necessária para a locomoção do cidadão. As obras importantes dessa proposta foram a abertura da BR-101, em 1971; a construção da ponte Colombo Salles, em 1974; a construção do Aterro da Baía Sul, em 1975.

Podemos destacar que com o crescimento econômico nacional da década de 1970, produto do desenvolvimento rápido da industrialização, e com o funcionamento das novas rodovias, os municípios de Florianópolis e São José uniram suas malhas urbanas num acelerado processo de conurbação, deixando novos espaços como alvo de especulação imobiliária. Essas glebas foram adquirias por especuladores fundiários locais (como empresários, políticos e outros) que, posteriormente, deram origem a loteamentos. Como exemplo, podemos citar a criação do bairro Kobrasol, um loteamento planejado, com fácil acesso tanto à capital quanto à BR-101.

Em Kobrasol e em Campinas, ambos em São José, o processo de verticalização se consolidou em 1990, com o incremento no limite de pavimentos permitidos. Anterior a esse ano, só eram permitidas construções de até dois pavimentos com uso exclusivamente residencial. Posteriormente, o gabarito permitido pela prefeitura passou para quatro andares, e segundo o Plano Diretor de 1987 (lei no. 1812), foi legitimada a construção de edifícios de quatorze pavimentos com a permissão de usos mistos. Assim, progressivamente a mudança da legislação favoreceu a verticalização desses setores.

Destaca-se nesse processo que pouco havia em termos de restrições urbanísticas e ambientais por parte do poder público municipal. Desse modo, as prefeituras não conseguiram impor qualquer tipo de ordenamento sustentável à cidade, "[...] era dado até certo incentivo por parte dos gestores municipais, para o desenvolvimento das construções verticais, pois essas obras geravam emprego e deixavam a cidade com cara de um grande centro urbano" (CAMPOS, 2010, p.134). 
Concomitante a isso, o setor turístico passou a adquirir relevância na ilha de Florianópolis, sendo promotor de novos produtos imobiliários nos balneários do norte, com prédios de quatro e oito andares, sobrados e casas térreas que mudaram completamente a paisagem natural na orla marinha. Destaca-se o balneário Ingleses, Canasvieiras e Jurerê e, mais recentemente, o setor sul da ilha ganhou importância, com os loteamentos Novo Campeche e Açores.

Por outro lado, em São José, Palhoça e Biguaçu, a construção de casas térreas, edifícios de dois e quatro pavimentos (dentro dos loteamentos preestabelecidos por outras incorporadoras) abriram caminho para que as novas empresas construtoras de menor porte achassem um espaço para crescer por meio do desenvolvimento dessas tipologias de moradia. Como assinala Campos (2010), os proprietários das pequenas construtoras que surgiram, em alguns casos, eram pedreiros que prestavam serviços de mão de obra, ou seja, eram empregados das grandes empresas desarticuladas por conta da crise econômica da década de 1980. Como, por exemplo, o fundador da construtora Beco-Castelo, ele foi empregado da construtora Ceisa que, ao se desarticular, empreendeu negócios imobiliários de forma independente (CAMPOS, 2010).

Atualmente, as empresas fundadas entre 1970 e 1980 têm expandido suas intervenções, optando pela verticalização. Por exemplo, a construtora Beco-Castelo tem $313.491 \mathrm{~m}^{2}$ de área construída em projetos residenciais e 470 salas comerciais. No início suas intervenções se centralizavam em São José; na década de 1990, expandiu suas construções em Florianópolis e hoje tem intervenções também em Biguaçu. A AM Construções e Incorporações, fundada em 1970, tem edificado $460.000 \mathrm{~m}^{2}$ de área, totalizando mais de 4.500 unidades habitacionais até 2018, entre suas intervenções está a construção do edifício Brasilar, primeiro prédio com 12 andares no Kobrasol, e o Residencial Alzemiro João Vieira, localizado em Campinas com 265 apartamentos e 34 lojas comerciais. Nos últimos anos, além de adquirir terrenos e construir prédios de grande porte, a construtora AM também adentrou no município de Palhoça, no Centro, e no Pagani .

Temos visto, em alguns casos, que um comerciante ou industrial próspero, não necessariamente inserido em negócios imobiliários, diversifica seus serviços ou comércio, criando uma incorporadora ou construtora pequena. Com o avanço das suas atividades imobiliárias, ele transforma sua empresa numa subsidiária ligada à produção imobiliária que envolve vários membros da família. Em algumas situações, esse crescimento pode ser tão dinâmico e auferir tantos ganhos que podem se expandir internacionalmente. Essas formas foram definidas por Lojkine (1997) como um novo tipo de "mobilidade do capital", característica específica da divisão monopolista do trabalho, em que a mobilidade dos investimentos age entre os diferentes ramos e as distintas esferas da economia.

$\mathrm{Na}$ área conurbada de Florianópolis, verificou-se que a mobilidade do capital aconteceu nas empresas mais fortes entre os membros de uma família, muitos deles descendentes de imigrantes estrangeiros que chegaram em Santa Catarina no século XIX. No início, essas famílias faziam outras atividades econômicas que serviram para a acumulação inicial de capital, ou seja, tratava-se da pequena produção mercantil. Como, por exemplo, a história da Construtora Dionísio Deschamps, que começou quando o francês Nikolaus Deschamps e a alemã Katharina Eich chegaram ao Brasil em 1828. Os descendentes desses migrantes fundaram em 1973 a empreiteira de mão de obra Irmãos Deschamps e juntos edificaram mais de vinte residências, até que em 1980 iniciaram a construção de seu primeiro empreendimento multifamiliar, o Residencial Maresol, com dezessete apartamentos no loteamento Kobrasol. No ano 2000, Dionísio Deschamps resolveu 
fundar uma segunda empresa em parceira com seus três filhos, a Construtora Dionísio Deschamps, a qual até hoje totaliza a construção de 1.391 apartamentos e 184 salas comerciais .

Nessa mesma linha, temos outro claro exemplo, o grupo Koerich, empresa que foi fundada por descendentes de alemães. A atividade comercial da família começou por volta de 1829, quando Eugênio Raulino Koerich iniciou a comercialização de produtos coloniais da região (KOERICH, 2014). Em 1975, foi instituído pelos filhos o Consórcio Koerich e a Construtora Zita. Seis anos depois, em parceria com os grupos Brasilpinho e Cassol, eles criaram a Kobrasol empreendimentos Imobiliários, e em 1993, a Koerich Imóveis, junto com outras empresas parceiras, construíram o primeiro centro comercial da ilha, o Beiramar Shopping, de seis andares. No início da década de 1990, a Koerich contava com pouco mais de mil funcionários distribuídos entre as construtoras Kilar, Dular, Koesa, Kimoto e Zita. O grupo tinha ainda participação nas empresas Macedo, Kobrasol e Beiramar Shopping. Em 2009, os irmãos Koerich unem-se uma vez mais e abrem a WOA. Verificamos que essa empresa tem edificado os prédios residenciais mais importantes da Beira Mar Norte dos últimos anos, todos com mais de dezenove pavimentos.

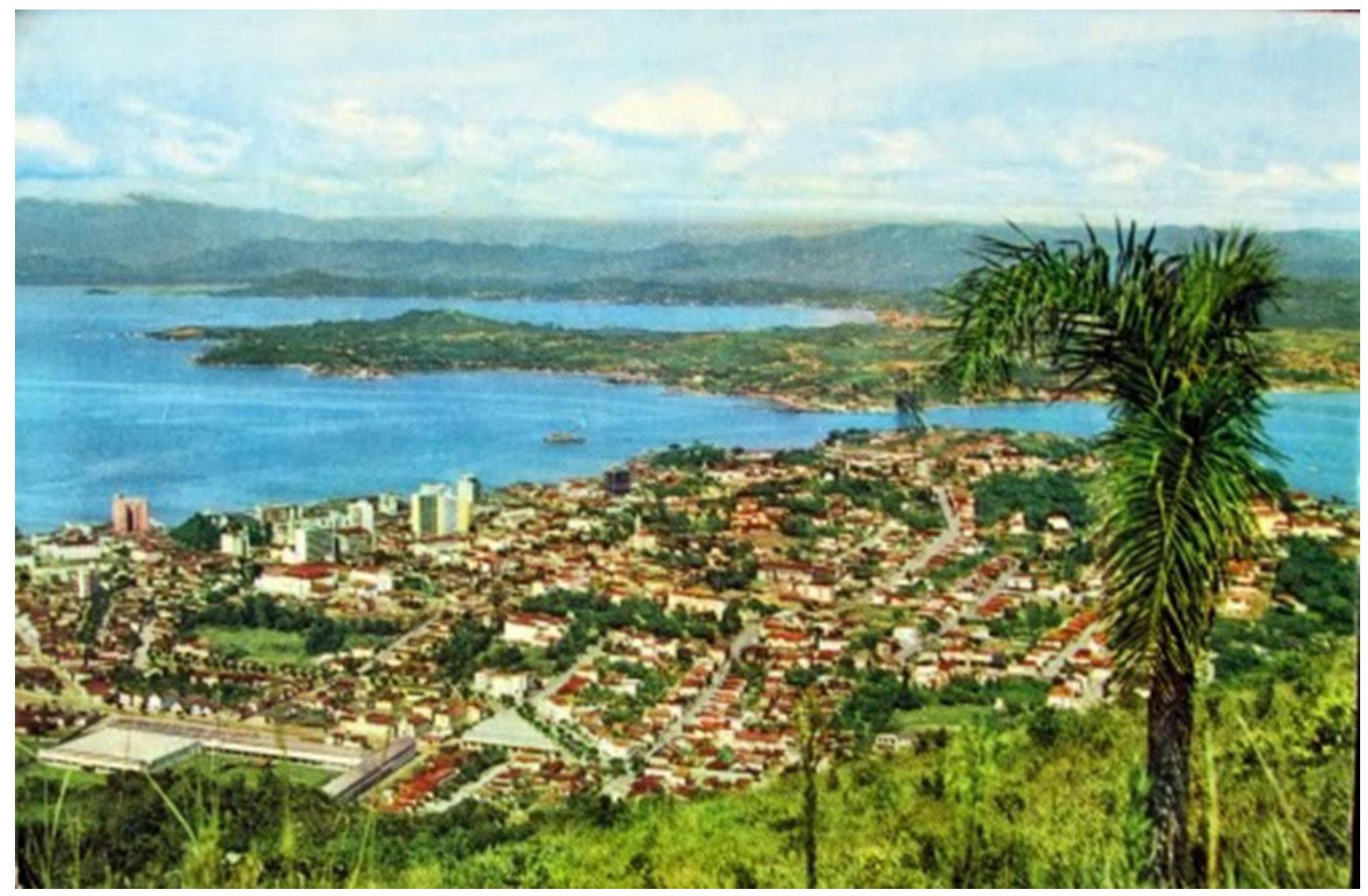

Figura 1. Início da verticalização no centro de Florianópolis na década de 1960. Fonte: <http://santiagosiqueira.blogspot.com.br/2014/>. Aceso em: 1 ago. 2014. 


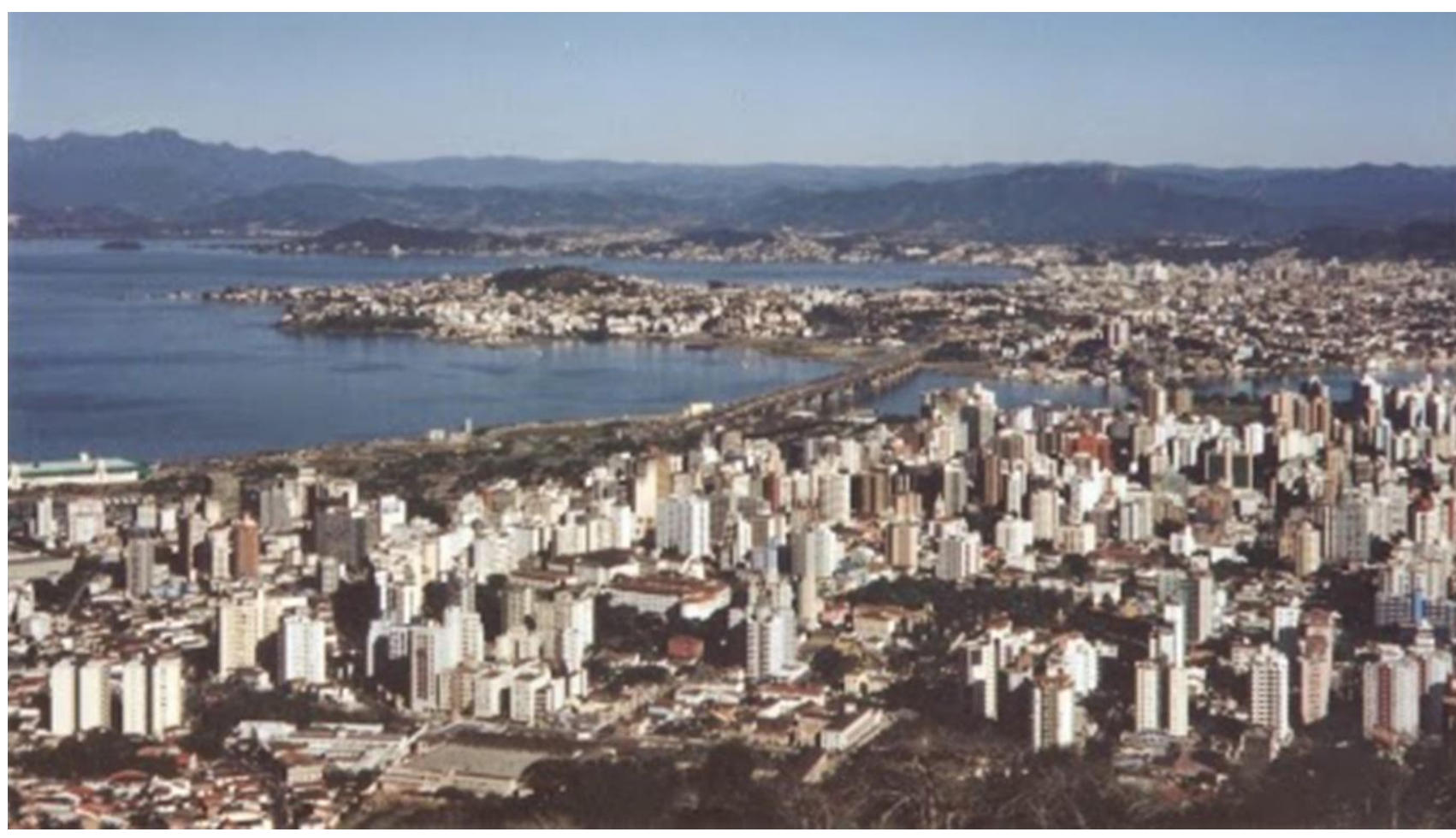

Figura 2. Verticalização e expansão de Florianópolis para o Continente em $1998 . \quad$ Fonte: <http://santiagosiqueira.blogspot.com.br/2014/>. Aceso em: 1 ago. 2014.

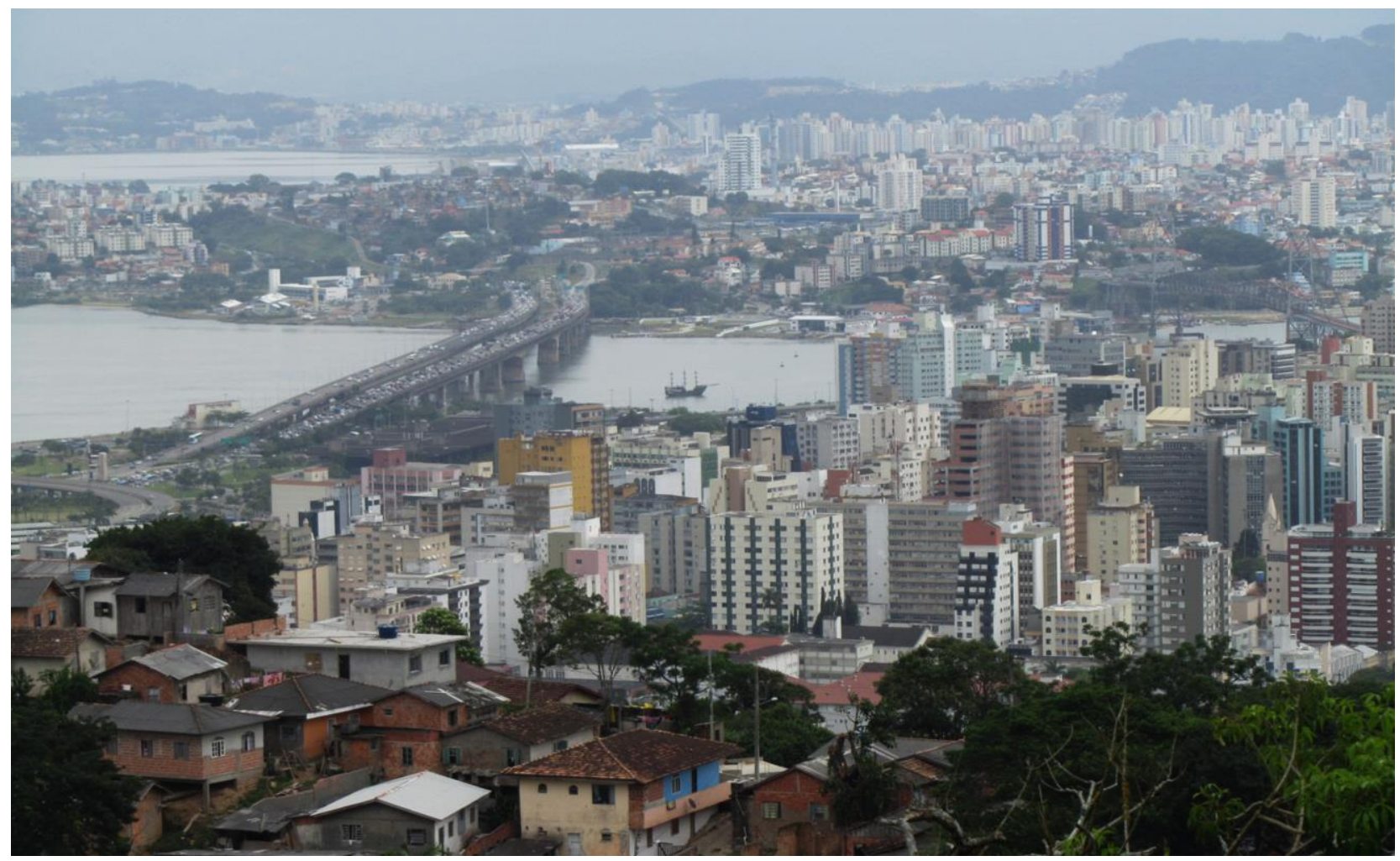

Figura 3. Consolidação da verticalização. Fonte: M. Hildebrandt, 2015. 
Ao observar o centro de Florianópolis panoramicamente (Imagens 1, 2 e 3), percebemos que o processo de verticalização foi rápido e se estendeu à área continental de forma muito clara. Desse modo, as últimas décadas do século XX foram fundamentais para a estruturação e o crescimento das empresas da construção civil. Sobretudo as décadas de 1970 e 1990, pois elas correspondem ao auge da expansão imobiliária da região, na qual as empresas se consolidaram por conta da ampliação no mercado, da intensificação da produção e da expansão do seu poder financeiro, graças aos processos de verticalização alcançados.

É importante ressaltar que mesmo com todo esse processo de verticalização descrito, a densidade que predominava em todo o núcleo metropolitano sempre foi muito baixa. A consolidação de áreas verticais é de apenas 5\%, com predominância de edifícios de quatro andares (FLORIANÓPOLIS, 2015). Então, podemos dizer que o processo de verticalização, começado no século XX na área de estudo, também se deu de forma fragmentada, pois ocupou áreas especificas de acordo com os interesses do capital financeiro-imobiliário. Consequentemente, excluiu outros setores à espera de valorização. Essa territorialização do processo de verticalização é uma prova da concentração do capital das empresas construtoras, em que o crescimento vertical representa a multiplicação dos lucros por meio do espaço.

Com tudo isso, não podemos afirmar que a reestruturação do crescimento urbano da década de 1970 e 1980 na RMF trouxe relações harmoniosas e neutras no uso do espaço. Pelo contrário, essas dinâmicas nos aproximaram mais profundamente da lógica das cidades capitalistas, onde existem conflitos que produzem desequilíbrio na estruturação do espaço e no funcionamento do mercado imobiliário, já que ele é dominado pelo lado da oferta e pelos interesses dos grupos imobiliários. Todavia, por mais que tenha ocorrido um processo de modernização, com base nas relações capitalistas, ainda há nos agentes produtores do espaço urbano, especialmente no capital imobiliário e na sua relação com o Estado, uma forte presença de relações conservadoras de poder, típicas de relações pré-capitalistas.

A reestruturação urbana ocorrida no final do século XX na área de estudo revela-se como uma nova estratégia de reprodução do capital. Nela a lógica de "consumo" é a protagonista, bem como o consumo do espaço e o consumo de bens e serviços. Diante do exposto, afirmamos que ocorreu um movimento de inflexão na lógica de reprodução das centralidades na Região Metropolitana de Florianópolis. Ele fez eclodir nas áreas periurbanas novos espaços e com eles novos fluxos intraurbanos, que estenderam a malha urbana de forma irregular e deficiente. Isso corresponde à gênese de muitos setores que hoje são importantes para as dinâmicas urbanas dos municípios em questão.

\section{Verticalização nas novas centralidades da área conurbada da Região Metropolita- na de Florianópolis no início do século XXI}

A própria produção do espaço reproduz novas áreas de acumulação para oferecer mais impulso às relações capitalistas. Essas relações também podem se dar por interações espaciais, criadas para se concentrar em forma de grupos intersetoriais que constituem parte de uma rede urbana. 
Para Corrêa (1994, p.87), uma rede urbana é "o conjunto funcionalmente articulado de centros, que se constitui na estrutura territorial onde se verifica a criação, apropriação e circulação do valor excedente". Sendo que, em cada uma, existe uma cidade ou um núcleo de forte hierarquia, segundo a aglomeração de atividades e funções que apresenta, e que podemos chamar também de centralidade.

Para Lojkine (1997), nessas centralidades agem com força as economias de aglomeração, nascidas da justaposição espacial das diferentes funções do capital e do conjunto das condições gerais da produção, em que a socialização da cooperação territorial atinge as novas formas de urbanização monopolista. Nessa visão, as "novas centralidades", o que nós chamaremos também de "subcentralidades", são outro aspecto da cooperação capitalista "que concentram atividades de comando e meios de formação de forças intelectuais de trabalho ou da descentralização das atividades e dos lugares de reprodução da força de trabalho não diretamente ligados aos centros nervosos da economia e do poder político" (LOJKINE, 1997, p. 167). Por sua vez Gottdiener (1997[1985]) descreveu as novas centralidades como um padrão contemporâneo de desenvolvimento submerso num processo de "desconcentração", referindo-se ao aumento absoluto de população e à densidade de atividades sociais em áreas fora das tradicionais regiões citadinas e dos centros populacionais.

Nessa perspectiva, buscamos situar o processo de formação espacial a partir da inserção dos municípios estudados na rede urbana e a criação de bairros que, com o passar do tempo, se revelam novas centralidades urbanas ou subcentralidades consolidadas. Para definir essas centralidades e subcentralidades a metodologia utilizada foi a análise dos componentes da formação socioespacial, bem como variáveis atuais de densidade demográfica, as atividades econômicas e imobiliárias, os fluxos de informações, mercadorias e pessoas, bem como fluxos de transporte e mobilidade urbana . Desse modo, identificamos suas hierarquias espaciais e as forças que agem nelas.

Encontramos, na nossa análise, basicamente cinco categorias de centralidades e subcentralidades organizadas no Mapa 2, a metodologia utilizada varia em relação ao tempo de consolidação das diferentes centralidades:

1) as centralidades históricas, onde o centro histórico de Florianópolis destaca-se por possuir a maior hierarquia da Região Metropolitana, por ser capital do estado de Santa Catarina e possuir funções administrativas, econômicas e políticas importantes. Os centros tradicionais são definidos pela análise da formação socioespacial, na qual inclui a densidade demográfica conjugada às atuais funções, as atividades econômicas e os fluxos da mobilidade urbana;

2) as subcentralidades que surgiram a partir da década de 1970, que formam no caso de Florianópolis núcleos com funções específicas dentro de bairros, como o da Trindade, com atividades educativas e laborais e o dos Ingleses, com funções de lazer. Por outro lado, em São José, surgem as subcentralidades de Kobrasol e Campinas, bairros com atividades mistas que ganharam tanta importância nas últimas décadas do século XX que substituíram, em termos de hierarquia, o centro tradicional de São José. Essas subcentralidades são definidas atualmente pelas altas densidades demográficas (31.838 hab./km²), pelas atividades econômicas, fluxos intensos de mobilidade, numa escala urbana fortemente verticalizada e com prédios de até 24 andares (82 metros de altura). 
3) subcentralidade turísticas e residenciais, já na década de 1990, o fenômeno da balnearização toma importância, consequentemente bairros como Jurerê internacional, os Ingleses e a Lagoa da Conceição se consolidam como distritos turísticos. Atualmente, esses bairros possuem uma população permanente que se abastece graças ao comércio e aos serviços locais, mas são dependentes da centralidade hierárquica de Florianópolis para desenvolver atividades de trabalho, educação ou serviços mais específicos. Por outro lado, na área continental, consolidaram-se outros setores formando subcentralidades residenciais periféricas, entre elas destacamos Forquilhinhas, Barreiros e Bela Vista, em São José, e o adensamento do bairro Ponte do Imaruim, em PaIhoça. Os núcleos desses setores possuem certa aglomeração de comércio e serviços, mas com qualidades urbanas deficientes pelo seu adensamento e crescimento espacial pouco planejado.

4) as subcentralidades de Forquilhas e Pagani, que tomaram forma a partir do início do século XXI graças às grandes dinâmicas de parcelamento do solo; esses aglomerados encontramse em processo de consolidação, com alta tendência a evolução graças as fortes atividades de incorporação. Para identificarmos essas novas centralidades fizemos um mapeamento exaustivo das atividades de incorporação de terras e os novos conjuntos habitacionais criados no período de 2003 a 2017 , e temos analisado a densidade demográfica impulsada por eles. Isto conjugado às atividades comerciais e de serviços que geram empregos, bem como os fluxos de mobilidade urbana e as novas vias de circulação implementadas. Tal análise deu como resultado esses núcleos de aglomeração.

5) a subcentralidade de Pedra Branca, que basicamente se constitui de uma grande área de parcelamento de solo (aproximadamente 300 hectares com 3.330 lotes residenciais e prédios de uso misto) que atualmente se encontra em processo de ocupação. Mas nos últimos seis anos os promotores imobiliários têm impulsionado a construção do seu núcleo central, onde optaram pela verticalização com torres de alto padrão, tecnologia construtiva e uma praça que centraliza as atividades urbanas. Esse subcentro se alinha como um dos polos tecnológicos e de negócios de Santa Catarina. A recente construção dos prédios (após o último censo de 2010) não permite o uso de dados específicos de densidades habitacional na área, mas a ocupação das residências, a instalação de comércios, e o funcionamento da Universidade do Sul de Santa Catarina (UNISUL) geram dinâmicas e fluxos importantes e com alta tendência de evolução.

Podemos observar a localização dessas centralidades e subcentralidades no mapa seguinte: 


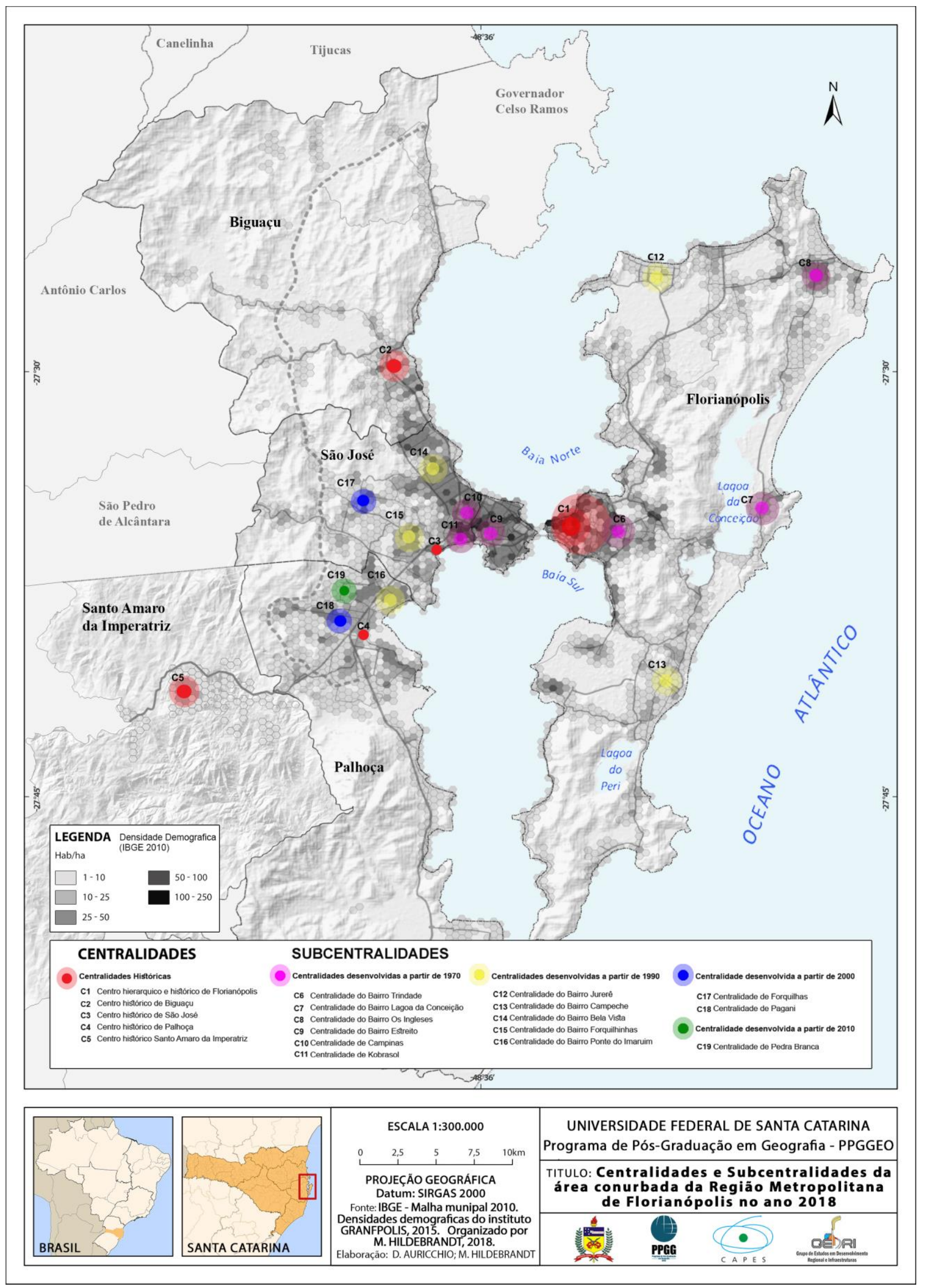

Mapa 02. Centralidades e Subcentralidades da área conurbada da Região Metropolitana de Florianópolis no ano 2018. Fonte: IBGE - Malha municipal 2010, GRANFPOLIS/Prefeitura de São José, 2015. Organização: M. Hildebrandt, 2018. 
Alertamos que nem todas as subcentralidades marcadas no Mapa 2 são compostas por processos de verticalização, a maioria delas são subcentralidades de tipo residencial, com médias e baixas densidades e sem a presença de edifícios verticais de mais de quatro andares. Para efeitos deste artigo, centraremos nossa explicação nas novas centralidades ou subcentralidades surgidas a partir do século XXI, com processos de verticalização.

\section{Subcentralidade de Kobrasol e Campinas em São José}

Como já foi analisado, nas últimas décadas do século $X X$, o crescimento vertical foi estimulado em alguns setores pelo poder público para que a paisagem regional tomasse a forma de um "grande centro urbano". Essas ideias continuaram repercutindo na primeira década do século XXI, quando se instituíram legislações para maior aproveitamento do solo em áreas centrais. Como, por exemplo, o setor de Kobrasol e Campinas no município de São José, onde as progressivas adequações ao coeficiente de edificação foram constantes nas últimas décadas do século XX. No ano de 2013, a Câmara Municipal de São José aprovou o gabarito de dezessete andares em áreas próximas à BR-101, visando justamente à verticalização, numa visão "progressista" do fenômeno. Por outra parte, destaca-se no setor de Kobrasaol a alta concentração de empregos existentes, segundo o IBGE (2010), ela é de 562 vagas de emprego por hectare. Tal índice pode ser comparado com o setor da Beira Mar Norte de Florianópolis, onde a concentração de empregos chega a ter cifras parecidas. Esse fator, junto com a densidade demográfica e a análise de deslocamentos são chaves catalizadoras para detectar novas concentrações de atividades.

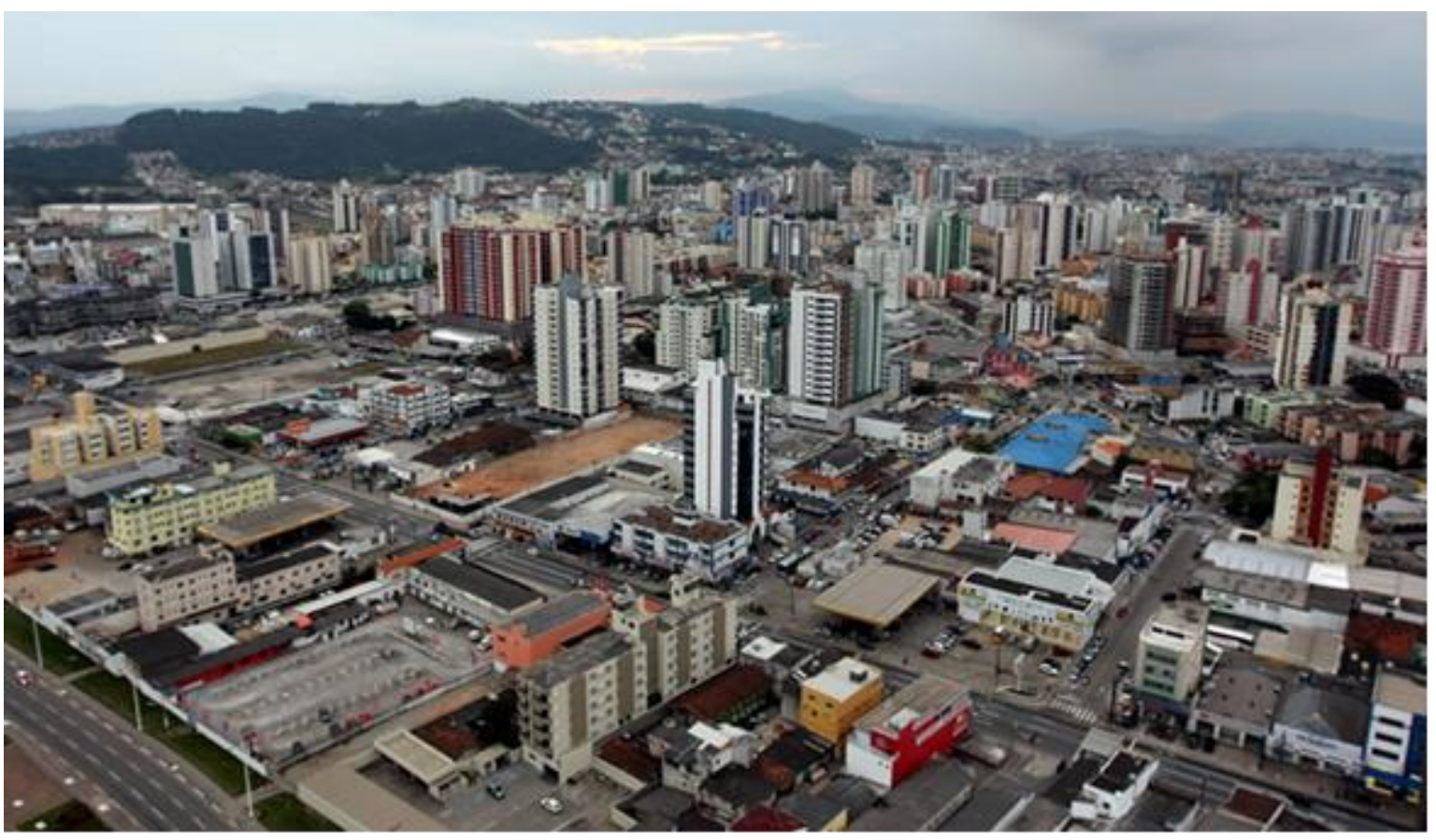

Figura 4. Verticalização no Bairro Kobrasol, em São José. Fonte: Diário Catarinense, julho 2015. 
Entretanto, ao analisarmos a configuração urbana atual das áreas com processos de verticalização avançados, como Kobrasol e Campinas, notamos claramente a deficiente construção do espaço público por parte do poder municipal. Assim, percebemos ruas não arborizadas, calçadas muito estreitas e fora dos padrões de acessibilidade, escassas áreas verdes e de lazer, além disso, o estreito afastamento entre os prédios de grande altura provoca pouca incidência de luz natural e largas horas de sombra, fatores importantes que são atribuídos à boa qualidade de vida.

Atualmente, o processo de verticalização se estende por outras zonas além do Estreito, de Kobrasol e de Campinas. Ele continua seguindo a linha da BR-101, independente do limite municipal. A BR-101 é um mosaico de todo tipo de edificações e espaços, que vão desde áreas vazias, áreas empobrecidas, áreas industriais, shopping centers, moradias com casas térreas, sobrados, assim como prédios de alturas variadas de distintos padrões. Notamos, ainda, à medida que nos afastamos dos bairros consolidados, os edifícios de vários pavimentos se fazem mais dispersos e começam a prevalecer áreas de densidades baixas e terrenos sem uso.

Por outro lado, a BR-101 também é uma vitrine para grandes empresas de construção e incorporação, como a RDO empreendimentos imobiliários, a OK Construções, a HS Construtora e Incorporadora, a Zilli Construções, a D. Dechamps Construções, a Lumis Construtora e Incorporadora, a Odlare, a Ferreira Antunes, a Kilar Construções e Incorporações, a PHM construtora, a Kreme, a ZITA Empreendimentos Imobiliários etc. Todas essas fazem questão de colocar suas marcas nas partes mais altas dos prédios para serem vistas das principais rodovias de acesso e passagem pela região.

\section{Subcentralidade de Pagani em Palhoça}

Uma das áreas da BR-101 que visivelmente tem crescido de forma vertical é o bairro Passa Vinte, especificamente o setor de Pagani, em Palhoça. Nesse setor se edificou o loteamento Pagani em 1999, criado pela Jota'S Empreendimentos Imobiliários. Seu estabelecimento (que inicialmente continha 550.371,89 $\mathrm{m}^{2}$ e 650 unidades), além da expansão do município, incentivou a transferência do seu núcleo central com a relocação dos serviços públicos e do comércio, com destaque para: a sede administrativa da Prefeitura, em 2001; a Câmara de Vereadores, em 2009; o Fórum Municipal, em 2011; assim como a construção do Shopping Via Catarina às margens da BR-101.

Por sua vez, o município incentivou a verticalização desse loteamento, e posteriormente, de todo o setor com uma série de legislações, como, por exemplo, instituindo a Lei do Solo Criado, no ano 2011 . Tal documento estabelece que as construtoras podem edificar até $10 \%$ a mais do preestabelecido e até quatro pavimentos de garagens em áreas de uso misto, sem prejuízo do gabarito já definido. Esses instrumentos da política urbana foram gerados no Estatuto das Cidades para serem incorporados nos Planos Diretores dos municípios, mas sua regulamentação não se vincula a impulsar a verticalização, e sim, atrela-se à justa distribuição dos benefícios e dos ônus decorrentes do processo de urbanização. 
A Lei do Solo Criado permitiu ao construtor a adequação de mais espaço para edificação de forma vertical, de acordo com o quadro de classificação de zoneamento estabelecido pelo Plano Diretor do município. Palhoça foi pioneira no estado ao estabelecer essa lei. Com o índice, os empreendedores podem adquirir até $10 \%$ a mais de área, desde que o projeto apresente como contrapartida sistemas de energia renovável, aproveitamento de água da chuva ou reaproveitamento de águas servidas e investimentos nas infraestruturas nas proximidades da obra. 


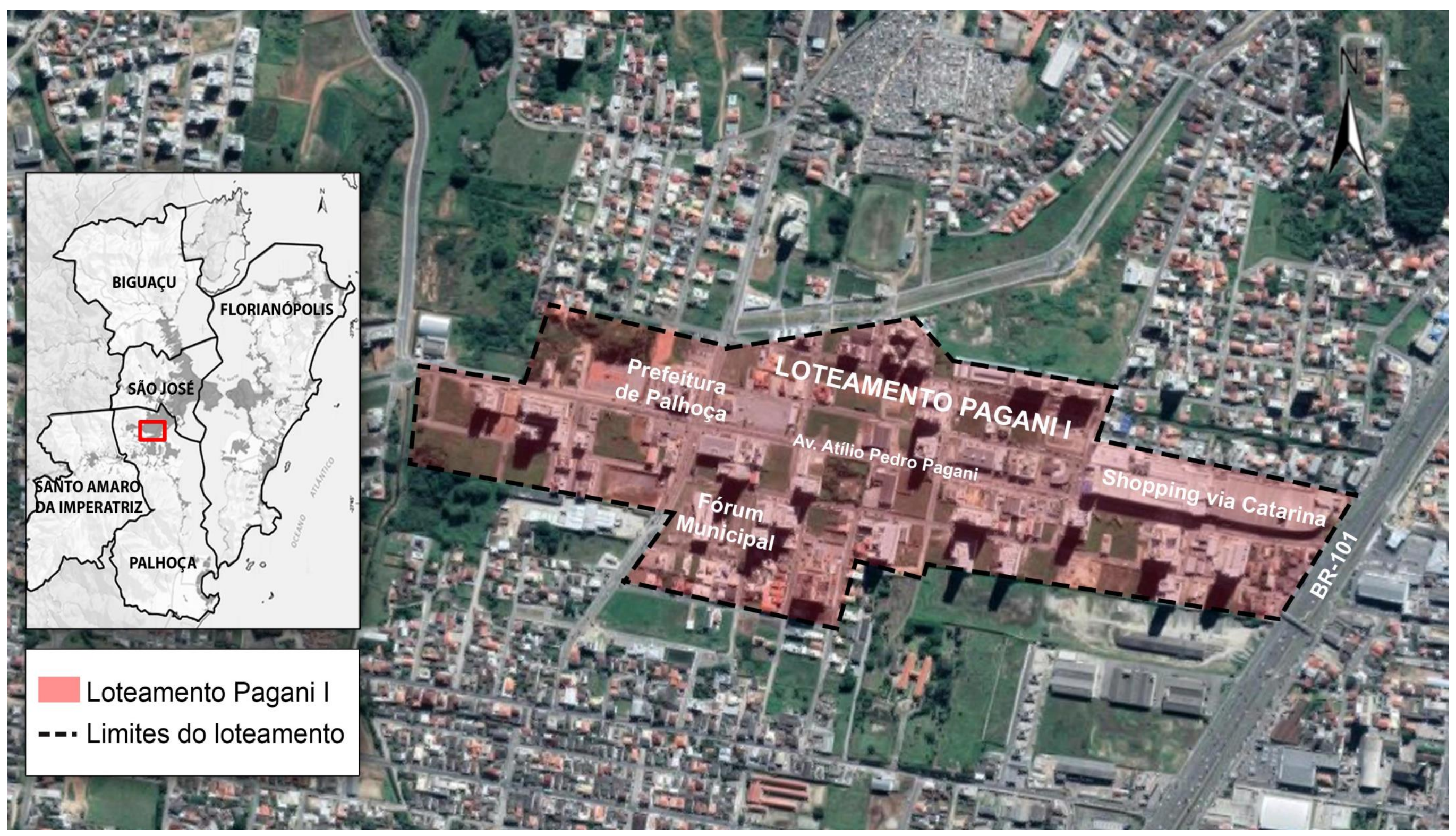

Figura 5. Loteamento Pagani, no bairro Passa Vinte, em Palhoça, RMF. Fonte: Mapa base Google Earth (Extraído em: mar. 2018). Organização: M. Hildebrandt 


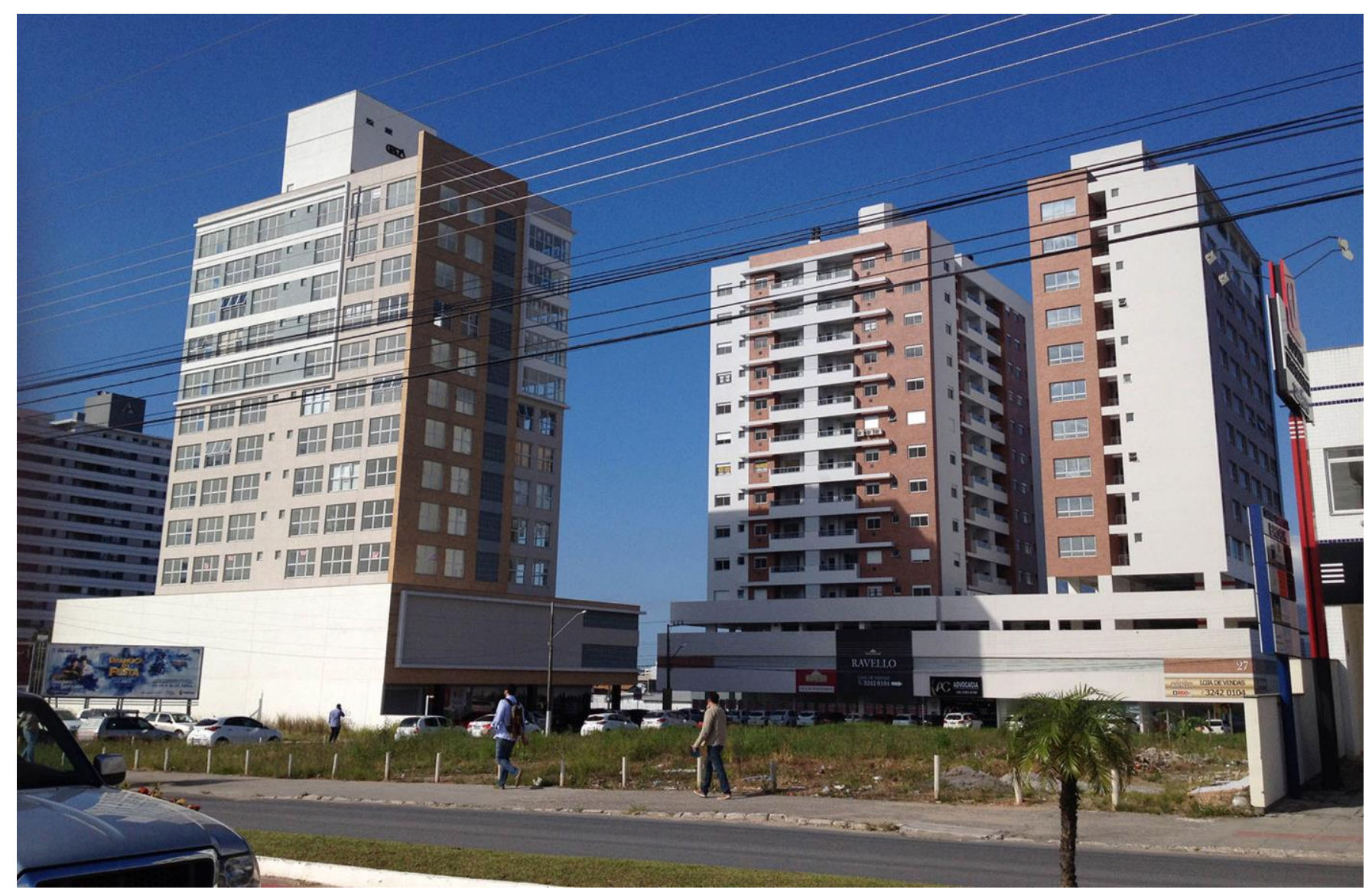

Figura 6. Verticalização no setor de Pagani em Palhoça, RMF. Fonte: M. Hildebrandt, 2017.

Nesse caso, percebemos que a implementação dessa legislação resultou na valorização de terrenos por causa da ampliação do coeficiente de edificação, permitindo a construção de até 21 pavimentos, podendo obter maior renda do solo. Sobre isso, Jaramillo (2009 [1995]) menciona um fenômeno que age nesse tipo de estrutura, a saber: "os preços de antecipação". Isso significa que os terrenos não se vendem nos preços que correspondem aos usos atuais, e sim, aos usos ou às densidades futuras. Verificamos isso quando comparamos os preços de terrenos em outras áreas de Palhoça onde não está permitida a construção de mais de quatro pavimentos e não está estabelecida a Lei do Solo Criado.

No caso de Pagani, também confirmamos a hipótese de que as economias de aglomeração fazem reproduzir com maior força o capital financeiro, pois os fluxos de pessoas são mais intensos graças ao estabelecimento do Via Catarina Shopping, conjugado com a acessibilidade veicular da BR-101 e as intervenções das construtoras RDO, Killar, Cota, Álamo, Habitatus, Zilli e Zul etc. Juntas, essas empresas investiram mais de R\$300 milhões na construção de prédios que misturam usos residenciais, instalação de escritórios, serviços e negócios, segundo a prefeitura de Palhoça. 


\section{A subcentralidade do bairro Pedra Branca}

O mesmo acontece com a centralidade exercida pelo loteamento Pedra Branca, que segundo seus criadores, foi desenhado baseado no conceito do New Urbanism Americano, com o intuito de formar um bairro onde houvesse funções múltiplas. Essa área era utilizada como fazenda de lazer e de agropecuária da família Gomez, proprietária do Grupo Portobello, grande grupo industrial do ramo de revestimentos cerâmicos catarinense desde 1979. No início do século XXI, a Portobello se expande no ramo da construção civil, tendo como eixo propulsor o terreno da antiga fazenda da família, onde uma das primeiras aspirações, segundo os investidores, foi formar uma nova centralidade para o município de Palhoça. No decorrer dos últimos dez anos, o bairro passou, e atualmente ainda passa, por um processo de implementação acelerada, em que se destaca inclusive a presença de investimentos das construtoras Cassol e RDO no bairro.

Num primeiro momento, os proprietários cederam um terreno à UNISUL, com o objetivo de atrair investidores e gerar fluxos. Logo, foi se desenvolvendo o parcelamento dos lotes e da urbanização, priorizando a formação de um eixo de ligação com a BR-101 e a praça central, e outro eixo que liga ao loteamento Pagani. Nos últimos seis anos, tem-se impulsionado o setor de usos mistos, que optou pela verticalização com torres de alto padrão, algumas com uso exclusivo de escritórios, outras de moradia e outras torres de usos mistos conectadas por passeios urbanos e uma praça que centraliza as atividades. Essas comodidades no espaço público fazem que seu uso seja cada vez mais contínuo. $\mathrm{Na}$ atualidade, isso reflete que um centro ou um subcentro não nasce como produto das funções urbanas, mas sim, dos investimentos imobiliários.

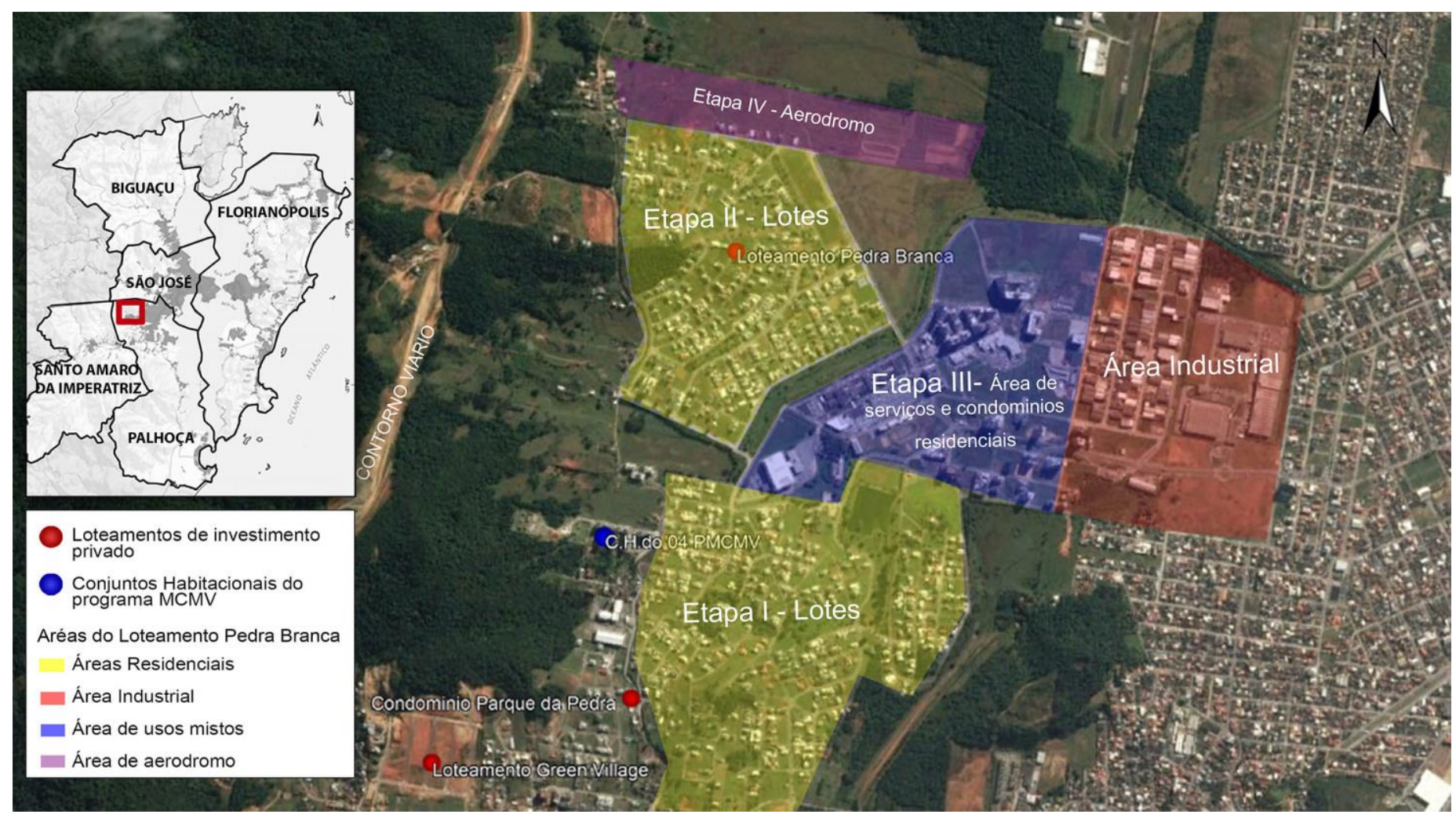

Figura 7. Etapas do Loteamento Pedra Branca, Palhoça na RMF. Fonte: Mapa base Google Earth (Extraído em: mar. 2018). Organização: M. Hildebrandt. 


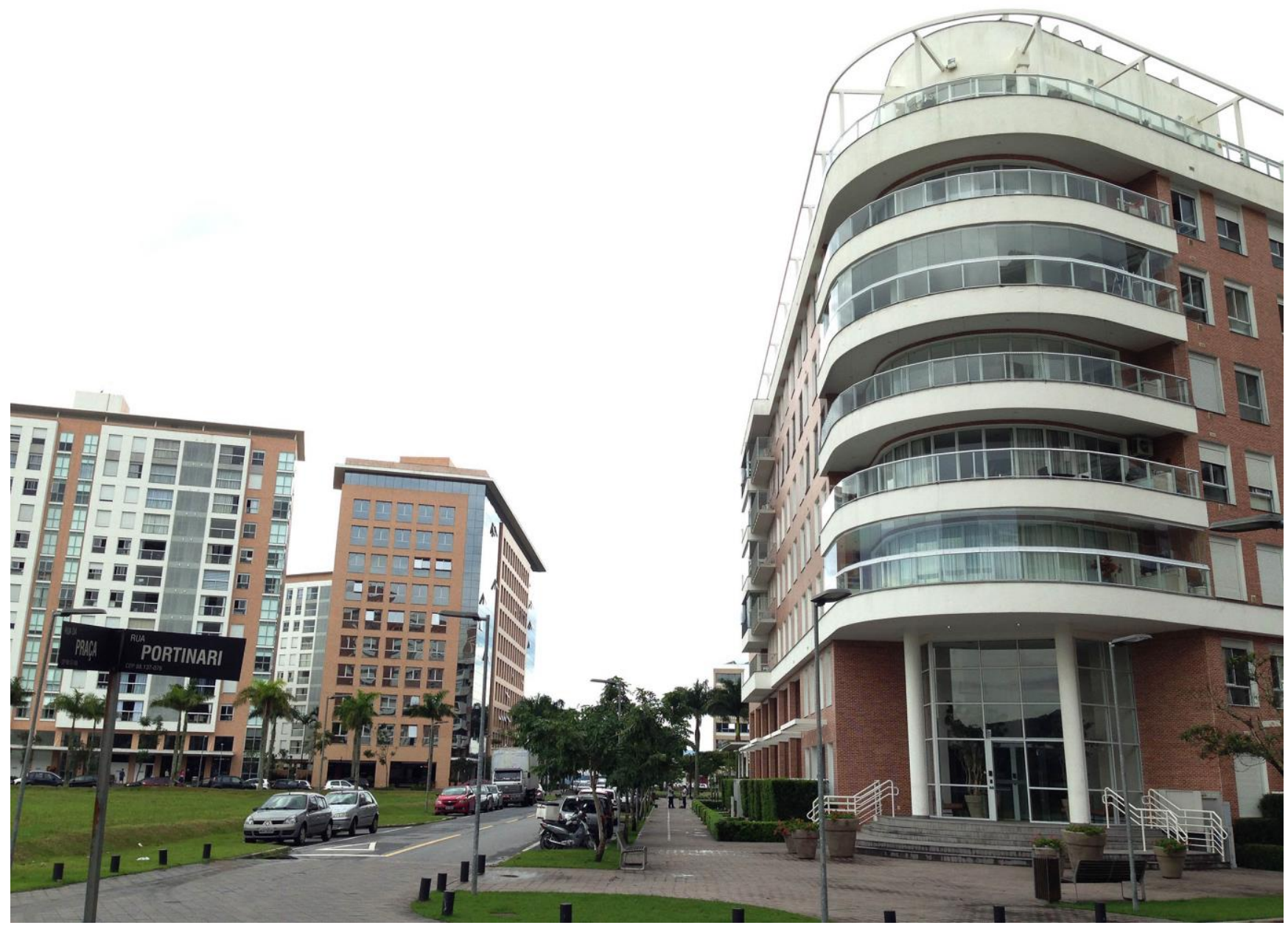

Figura 8. Centro do bairro Pedra Branca em Palhoça. Fonte: M. Hildebrandt, 2017.

Por outra parte, no Pagani ou no Pedra Branca, a paisagem revela espaços em que a propriedade parece auferir rendas tão altas quanto as áreas mais nobres da capital, como a Avenida Beira Mar Norte ou a Avenida Rio Branco, já que nelas se edificam modernas intervenções de alto padrão, acompanhadas pela instalação de empresas ou marcas que são atrativas para o consumo, quando, na verdade, a maior parte da população de Palhoça não tem a capacidade aquisitiva para desfrutar os produtos que o setor imobiliário oferece.

Podemos destacar que o processo de verticalização também acontece nas áreas de expansão de forma dispersa. Essa ideia se respalda no fato de que grande parte das intervenções do programa MCMV (Minha Casa Minha Vida), construídas na área conturbada da RMF (27.911 unidades habitacionais distribuídas em 1.200 empreendimentos), apropriaram-se da tipologia de prédios que vão desde quatro a oito pavimentos, sendo a construção de edifícios de quatro andares a mais comum por não ter como exigência a instalação de elevadores. As intervenções se- 
guem um padrão repetitivo com pouco ou nenhum tratamento de fachadas, o que dá como resultado aglomerados habitacionais monótonos sem qualidade arquitetônica, nem relação com seu entorno. Também vale ressaltar o fato de que a empresa construtora é a responsável pela aquisição do terreno, cujo montante não deve superar 15\% do valor total da obra, e posteriormente, o valor do terreno é reembolsado mediante parcelas à construtora. Esse valor mostra-se realmente

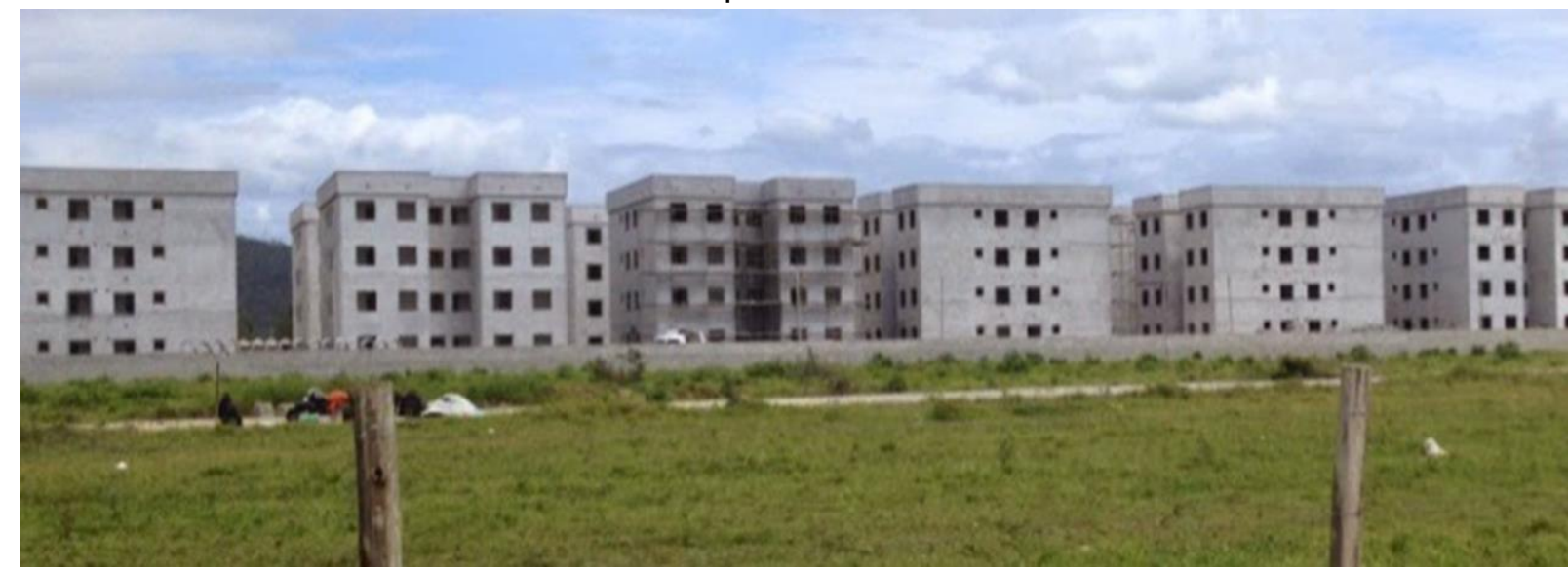

baixo para a aquisição de terrenos localizados em áreas urbanizadas, já que ele ultrapassa os patamares estabelecidos pelo programa.

Figura 9. Conjunto Habitacional Adar F. Thiesen, bairro Guarda do Cubatão, Palhoça, RMF. Fonte: M. Hildebrandt, 2014.

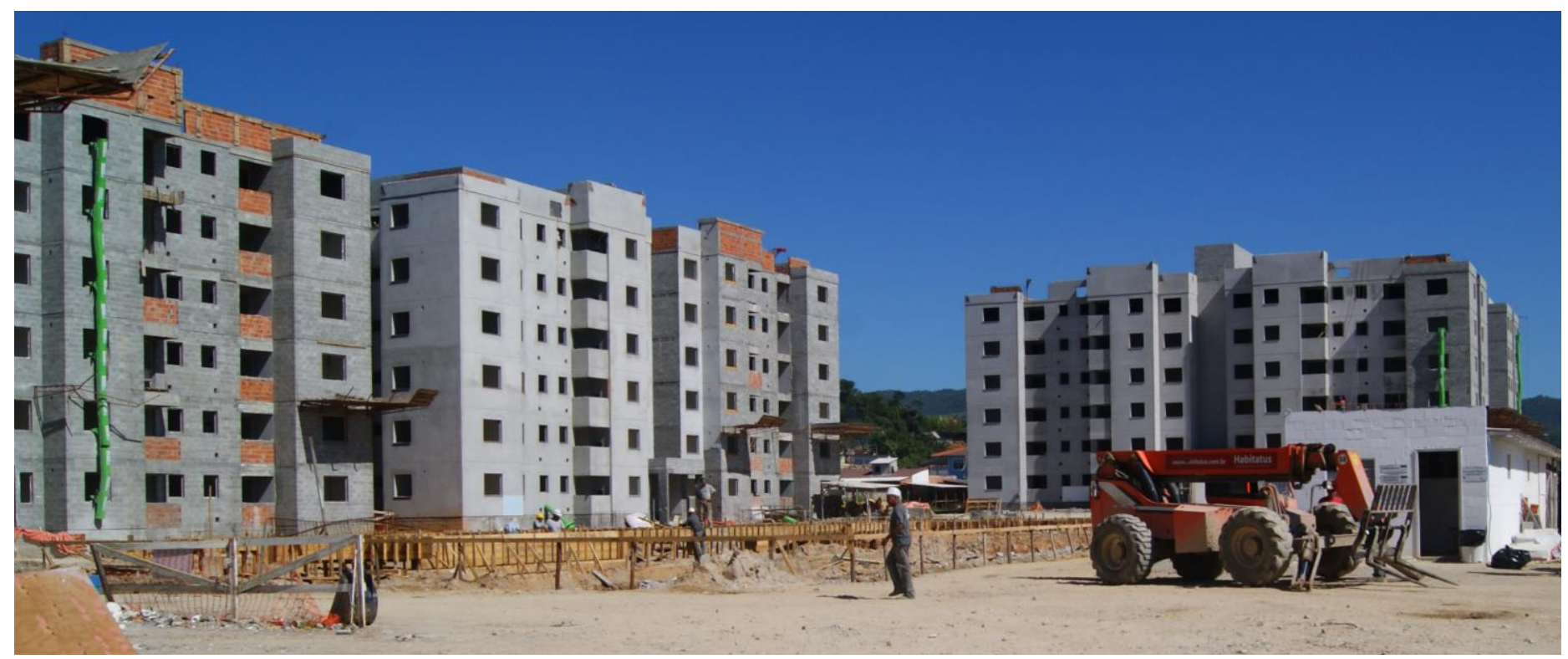

Figura 10. Conjunto Habitacional Bosque das Estações, bairro Bela Vista, Palhoça, RMF. Fonte: M. Hildebrandt, 2014.

O valor dos terrenos e a porcentagem da área edificável neles é o que torna viável o investimento, pois quanto mais apartamentos puderem ser construídos no terreno ou mais lotes pos- 
sam ser atingidos, a construtora poderá obter maiores lucros por um capital financeiro similar. Assim, o coeficiente edificável do terreno é um detalhe muito importante, em outras palavras, é crucial o número máximo de pavimentos que se pode atingir numa determinada área.

Dessa mesma forma, um empreendimento contratado do programa MCMV pode impulsionar, no futuro, o adensamento populacional de um bairro periférico através da verticalização e mudar de forma radical a paisagem das áreas periurbanas, além de aprofundar o processo de extensão da malha urbana.

Com tudo isso, há certa dificuldade no processo de ocupação dos novos subcentros de localização periférica, como o Pagani e o Pedra Branca e os empreendimentos de grande escala do programa MCMV, pois existe uma clara especulação imobiliária sobre os lotes e/ou apartamentos não ocupados. Nesse contexto, entram em conflito os princípios da função social da propriedade urbana e as forças das dinâmicas privadas de extração de renda do solo urbano.

Isso é um reflexo de que o setor financeiro-imobiliário reproduz centralidades impulsionadas pela verticalização devido às necessidades de reprodução do capital, e não, por uma demanda real da população, tanto que seus produtos são significativamente dirigidos a estratos socioeconômicos de outros centros urbanos com hierarquia nacional e internacional, não compatibilizando com a realidade local dos municípios da área conurbada.

\section{Considerações finais}

Atualmente, a indústria da construção civil se fortalece com arranjos financeiros muito mais complexos, com processos poderosos, focados na apropriação radical do espaço e na absorção do maior lucro por meio da verticalização. Os casos estudados nos levam a afirmar que desde que se iniciou o processo de verticalização (a partir do setor Centro e na Beira Mar Norte) de Florianópolis, ele foi, nas últimas décadas do século $X X$, incentivado pelo poder público municipal. Dessa forma, o que aconteceu foi uma expansão urbana e uma verticalização com o objetivo que a cidade tome forma de uma grande metrópole, onde os edifícios e as rodovias são interpretadas pelos agentes públicos e produtores do espaço urbano os componentes urbanos mais importantes.

Esse impulso do setor público foi absorvido diretamente pela indústria da construção civil. Nesse contexto, nas últimas décadas do século $X X$, houve uma importante fase de expansão imobiliária, cujas repercussões mudaram de forma radical o perfil da cidade e o processo de metropolização. Foi nessa época que nasceram as empresas do ramo imobiliário mais importantes da região, responsáveis pela construção de edifícios de vários pavimentos. Algumas delas, reestruturadas e com maior capital financeiro, trabalham até hoje na área de estudo, por exemplo, temos: a Becocastelo Construções e Incorporações; a AM Construções e Incorporações; a Cota Empreendimentos Imobiliários; a Kobrasol Empreendimentos Imobiliários; a D. Dechamps Construções; a OK Construções; a ZITA Empreendimentos Imobiliários; a Jota's Empreendimentos Imobiliários; a Koerich Construções; dentre outras. 
As dinâmicas das atividades imobiliárias dessas empresas foram fundamentais para a configuração do espaço urbano atual. O centro de Florianópolis, no setor da Beira Mar Norte, e no bairro Estreito, assim como em São José, os setores de Barreiros, Campinas e Kobrasol impulsionaram um profundo processo de ocupação de espaços vazios e/ou rurais e promoveram a verticalização acelerada que mudou a paisagem de forma radical. Essas empresas foram incentivadas, em grande parte, pelas políticas desenvolvimentistas dos poderes públicos municipais, pelos créditos e pelas facilidades de financiamento outorgados na Caixa Econômica Federal, via Fundo de Garantia do Tempo de Serviço - FGTS.

As forças que exerceram essas incorporadoras e construtoras mediante o capital financeiro-imobiliário recaíram sobre o espaço urbano, adensando setores conforme suas necessidades. Elas centralizam os fluxos de pessoas e criam espaços de consumo segregativos e mal resolvidos do ponto de vista urbanístico, como, por exemplo, o setor mais denso da RMF, que é o bairro Kobrasol. Esse bairro se caracteriza por ter edifícios de grande altura, mas é deficiente na construção do espaço público, de ruas e calçadas estreitas, não arborizadas, descontínuas e falta áreas verdes e de lazer.

Essas caraterísticas demonstram que a formação socioespacial da RMF esteve marcada por um planejamento urbano que beneficia alguns setores, segundo os interesses da indústria da construção civil e do mercado imobiliário, mas deixa de lado os interesses coletivos da população. Por outra parte, podemos dizer que os processos intensos de crescimento vertical, impulsionados pelos monopólios da indústria da construção civil, aprofundam a fragmentação do ponto de vista social e espacial, pois sobre eles regem os preços de antecipação visando densidades futuras, sublevando o valor de troca, antes que o valor de uso. No mesmo sentido, o loteamento Pagani e a área central do loteamento Pedra Branca se configuram como novos subcentros de usos mistos (negócios, comércio e também de residências). Ambos coincidem no tipo de público para o qual são orientados, pois respondem a áreas bem servidas por mobiliário urbano, e por conseguinte, o produto imobiliário oferecido aufere uma alta valorização, não sendo compatível com a população do seu entorno, resultando disso uma intensa segregação socioespacial.

Nesses casos, evidenciamos que essas centralidades em processo de ocupação não surgiram graças a um planejamento urbano concertado e democrático. Elas são resultado da concentração de capitais dos diferentes ramos da indústria da construção civil no espaço sob a aprovação e o amparo dos governos locais. A origem desses empreendimentos, aliado à condição de município industrial e da implantação de outras grandes obras fazem ver o município de Palhoça como um centro de expansão imobiliária, já que representa um grande polo de interesse de grandes investidores que marcaram definitivamente um processo de reestruturação econômica e urbana liderada pelo capital privado.

Por outro lado, a produção de habitação do programa MCMV é feita sob um padrão de projeto repetitivo que incentiva à verticalização por conta do maior aproveitamento do espaço, só que suas intervenções estão sendo feitas em áreas periféricas ou periurbanas, onde os municípios não contam com projetos urbanos bem definidos, deixando outros terrenos centrais vazios ou subutilizados. 
Ademais, o motivo das construtoras escolherem edificar só quatro andares se deve ao fato de que acima desse nível o programa MCMV exige a instalação de elevador. Tal aspecto tem sido decisivo para a repetição dessa altura na grande maioria condomínios de habitação popular. Por conta desses empreendimentos, o panorama que se tem nas periferias é de uma mistura de diferentes densidades e tipologias habitacionais, as quais atingem a paisagem natural e rural do entorno, mas com deficiente ou nenhum tratamento do espaço público.

Submetido em 24 de outubro de 2019.

Aceito para publicação em 07 de julho de 2019 
BORJA, Jordi; MUXÍ, Zaida. El espacio público, ciudad y ciudadanía. Barcelona 2000.

CAMPOS, Édson Telê. A Expansão Urbana na Região Metropolitana de Florianópolis e a Dinâmica da Indústria da Construção Civil. Editora Insular. Florianópolis 2010.

CORRÊA, Lobato. Estudos sobre a Rede Urbana. Editora Ática S.A. São Paulo, 1994.

FARRET, Ricardo. Paradigmas da estruturação do Espaço Residencial Intra-Urbano. Projeto Ed., 1985

GOTTDIENER, Mark. A produção social do espaço urbano. São Paulo: Edusp, 1997, 2a edição, $310 \mathrm{p}$.

HILDEBRANDT, Margaux. As dinâmicas de metropolização e a atuação dos agentes produtores do espaço urbano na área conurbada de Florianópolis. Tese de doutorado do Programa de Pós-graduação em Geografia da Universidade Federal de Santa Catarina. Florianópolis, 2018.

JARAMILLO, Samuel. Hacia una teoría da la renta del suelo urbano. Universidad de los Andes. Bogotá, 2009.

$\mathrm{KOERICH}$, Eduardo. Trajetória das organizações KOERICH durante período conturbado da economia brasileira de 1955 a 2002: como se sustentar em uma economia de mercado instável. Monografia submetida ao Curso de Ciências Econômica. UFSC, 2014.

LEFEBVRE, Henri. A Revolução Urbana. Editora UFMG, 2008.

LOJKINE, Jean. O estado capitalista e a questão urbana. São Paulo: Martins Fontes, 1997.

MAMIGONIAN, Armen. Industrialização de Santa Catarina. Atlas de Santa Catarina, Florianópolis; Gaplan, 1987.

SOUZA, Maria A. (org.). A identidade da metrópole: a verticalização de São Paulo. São Paulo: EDUSP, 1994.

SOMEKH, N. A(des)verticalização de São Paulo. Dissertação (Mestrado), São Paulo: FAUUSP, 1987.

SUGAI, Maria Inês. Segregação silenciosa: investimentos públicos e dinâmica socioespacial na área conurbada de Florianópolis (1970-2000). Florianópolis: Editora da UFSC, 2015.

Páginas de internet consultadas

FLORIANÓPOLIS/IDOM-COBRAPE. Crescimento Urbano da prefeitura de Florianópolis. Relatório final, Estudo $\quad N^{\circ} 3, \quad 2015 . \quad$ Disponível em <http://www.pmf.sc.gov.br/arquivos/arquivos/pdf/27_08_2015_9.30.19.2d57c5303b800097a b78796419b761af.pdf>. Acesso em: 20 ago. 2018. 
IBGE - Instituto Brasileiro de Geografia e Estatística. Estimativas 2017. Disponível em: $<$ https://www.ibge.gov.br/estatisticas-novoportal/>. Acesso em: 1 mar. 2018.

IBGE - Instituto Brasileiro de Geografia e Estatística. Sinopse por setores 2010. Disponível em: <https://censo2010.ibge.gov.br/sinopseporsetore>. Acesso em: 1 mar. 2018.

Plano de Mobilidade Urbana Sustentável da Grande Florianópolis - PLAMUS / Florianópolis: Logit Engenharia Consultiva. Produto 19, Relatório Final - Consolidação das Propostas e Plano de Implementação. 2015. Disponível em: <http://www.plamus.com.br/>. Acesso em: março, 2018.

Construtora Dionísio Deschamps Ltda. Disponível em: <http://ddeschamps.com.br>.. Acesso em: 10 jan. 2018.

AM Construções e Incorporações. Disponível em: <http://amconstrucoes.com.br>. Acesso em: 10 jan. 2018.

Blog Santiago Siqueira. Disponível em: <http://santiagosiqueira.blogspot.com.br/2014/>. Acesso em: 15 ago. 2014 